\title{
PKMS Kelompok Usaha Bersama (KUBE) Ibu Rumah Tangga Penghasil Aneka Cemilan Khas Kampar di Desa Merangin
}

\author{
Zayyinul Hayati Zen*1, Denny Astrie Anggraini2 \\ ${ }^{1,2}$ Fakultas Teknik, Universitas Muhammadiyah Riau \\ email: zayyinulhayati@umri.ac.id
}

\begin{abstract}
Merangin Village has several Joint Business Groups (KUBE) Housewives. One of them is KUBE Berkat Yakin. KUBE is managed by creative housewives who gather together and have a high desire to work to help the family economy. KUBE produces various typical Kampar snacks, such as: Lomang Crackers, Jengkol Crackers, and other Kampar special snacks. Some issues that become a problem for KUBE Berkat Yakin include: KUBE production capability is still low because the workmanship is still manual using simple kitchen equipment, lack of capital and limited access to capital for development, lack of good financial management, product packaging is still very simple and unattractive, and management of the organization that has not been running optimally. The goal of the Merangin Village KUBE PKMS is to increase production quantity, accompanied by an increase in product quality, and more attractive product packaging and business management in a professional manner so as to be able to introduce its products in the form of various typical snacks Kampar to local, national, and even international communities. The output provided was in the form of assistance to increase knowledge of human resources about the snack food industry, the development of attractive packaging designs and professional business management so that the product marketing area is wider and can increase the sales turnover of KUBE Berkat Yakin.
\end{abstract}

Keywords: typical Kampar snacks, packaging design, KUBE, business management

\begin{abstract}
Abstrak
Desa Merangin memiliki beberapa Kelompok Usaha Bersama (KUBE) Ibu-ibu Rumah Tangga. Salah satunya adalah KUBE Berkat Yakin. KUBE dikelola oleh ibu-ibu rumah tangga kreatif berkumpul bersama dan mempunyai keinginan tinggi untuk berkarya guna membantu perekonomian keluarga. KUBE ini menghasilkan aneka cemilan khas Kampar, seperti : Kerupuk Lomang, Kerupuk Jengkol, dan cemilan khas Kampar lainnya. Beberapa hal yang menjadi permasalahan bagi KUBE Berkat Yakin ini antara lain : kemampuan produksi KUBE yang masih rendah karena pengerjaan masih manual dengan menggunakan peralatan dapur sederhana dengan tenaga kerja diri sendiri, kurangnya permodalan dan keterbatasan akses permodalan untuk pengembangan, belum adanya manajemen keuangan yang baik, kemasan produk masih sangat sederhana dan kurang menarik, serta belum berjalannya manajemen organisasi kelompok dalam pengelolaan KUBE. Sasaran PKM KUBE Desa Merangin ini diharapkan kedepannya mampu meningkatkan produksi, diiringi dengan peningkatan kualitas produk, dan perbaikan kemasan produk yang lebih menarik serta pengelolaan usaha secara profesional sehingga mampu memperkenalkan produknya berupa aneka cemilan khas Kampar ke masyarakat lokal, nasional, bahkan internasional. Output yang diberikan berupa pendampingan peningkatan pengetahuan SDM tentang industri makanan cemilan, pengembangan desain kemasan yang menarik dan pengelolaan usaha secara profesional agar daerah pemasaran produk semakin luas dan dapat meningkatkan omzet penjualan KUBE Berkat Yakin.
\end{abstract}

Kata Kunci: cemilan khas Kampar, desain kemasan, KUBE, pengelolaan usaha

\section{PENDAHULUAN}

Desa Merangin merupakan salah satu desa yang ada di kecamatan Kuok, Kabupaten Kampar, Propinsi Riau. Desa ini berjarak sekitar $70 \mathrm{~km}$ dari kampus Universitas Muhammadiyah Riau. Disini terdapat 3 Dusun, 6 Rukun Warga (RW) dan 12 Rukun Tetangga (RT). Penduduk 
di desa ini pada umumnya berprofesi sebagai petani dan pedagang. Ibu-ibu (para istri) banyak yang berdiam di rumah hanya sebagai Ibu Rumah Tangga.

Berdasarkan survey awal ke Desa Merangin, Kecamatan Kuok, ditemukan bahwa sudah ada Kelompok Usaha Bersama (KUBE) yang aktif dan berpotensi bagus untuk dikembangkan di kelurahan ini. Kelompok itu dikenal dengan nama KUBE Berkat Yakin. KUBE ini adalah suatu kelompok usaha yang terdiri dari beberapa orang anggota yang merupakan ibu rumah tangga yang ada di Desa Merangin. Mereka berkumpul, bekerja bersama-sama untuk mengembangkan diri melalui beberapa kegiatan. KUBE ini telah menghasilkan aneka cemilan khas Kampar, seperti : Kerupuk Lomang, Kerupuk Jengkol, dan cemilan khas Kampar lainnya. Produk utama dari KUBE ini adalah Kerupuk Lomang yang memiliki rasa spesifik, lebih gurih, beda dari kerupuk berbahan dasar ubi kayu lainnya. Mereka sudah mengembangkan 2 rasa kerupuk lomang, yaitu dikenal dengan "kerupuk lomang lado merah" dan "kerupuk lomang lado hijau".

Proses produksi dilakukan berdasarkan orderan dari masyarakat Kuok, kampar, Pekanbaru dan sekitar, serta beberapa diproduksi untuk dititip di beberapa tempat penjual kue dan kedaikedai kopi, dan ikut serta dalam beberapa kegiatan bazar.

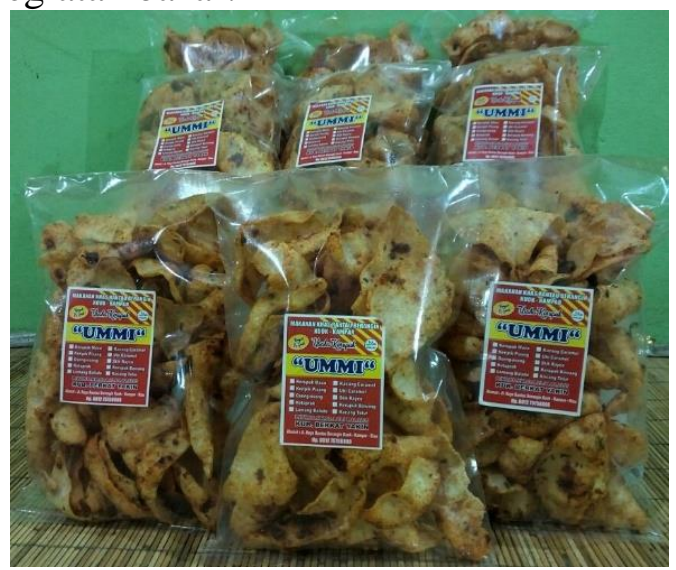

Gambar 1. Produk Mitra "Kerupuk Lomang Balado"

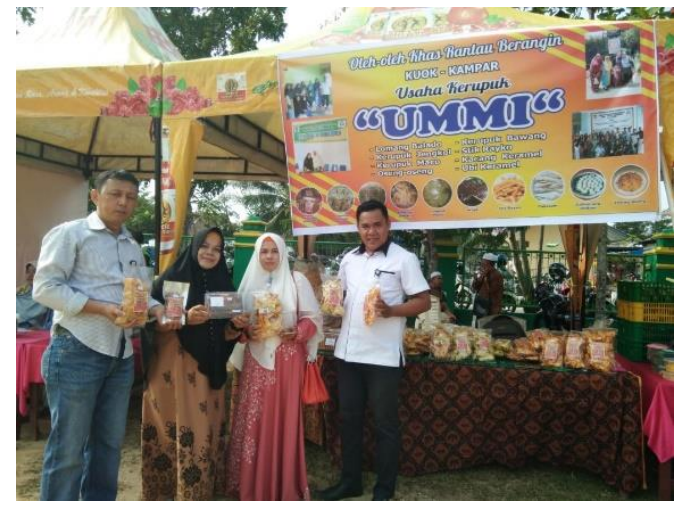

Gambar 2. Produk mitra pada Bazar Kab.Kampar

a. Dari Sisi Produksi : Kemampuan produksi masih rendah karena prosesnya dilakukan secara masih manual, mulai dari pengupasan ubi kayu yang digunakan sebagai bahan baku utama, pemotongan, perebusan, hingga penggorengan kerupuk lomang, masih kurang informasi mengenai peluang pasar atas aneka produk yang bagus untuk diproduksi dan dikembangkan sebagai ciri khas Kampar.

b. Dari Sisi Manajemen Pengelolaan : Minimnya permodalan dan keterbatasan akses permodalan, sumber dana mitra selama ini hanya berasal dari modal sendiri, belum ada pencatatan kas harian, aliran uang masuk dan uang keluar, sering bercampurnya dana usaha dengan dana rumah tangga.

c. Dari Sisi Pemasaran : Kemasan yang masih standar dan kurang menarik, menggunakan plastik tipis transparan dan pengelemen masih menggunakan lilin, dikerjakan secara manual dan belum memiliki pelabelan yang layak yang menunjukkan masa kadaluarsa produk, dan belum menonjolkan kekhasan rasa yang ditawarkan pada produk, (misal sajian enak, lezat, bergizi, gurih, khas Kampar), belum ada sarana untuk memasarkan produk dengan maksimal, dan anggota mitra masih pasif dalam menggunakan 
media sosial sebagai media promosi. Artinya selama ini masih menggunakan cara lama dalam memasarkan produk yaitu hanya menunggu pesanan datang.

Dengan dijadikannya KUBE Berkat Yakin sebagai sasaran utama atau mitra dalam program ini, diharapkan dapat dijadikan sebagai motor penggerak bagi KUBE lainnya di Desa Merangin, Kecamatan Kuok untuk mengembangkan usaha kreatif dengan konsep manajemen terpadu. Pengembangan usaha kreatif bisa meningkatkan permintaan pasar melalui website dan media sosial lainnya. Dengan permintaan yang besar dapat mendorong meningkatnya produk aneka cemilan khas Kampar yang dihasilkan pada KUBE tersebut. Harapan terbesar kita adalah terbentuknya icon cemilan khas kampar pada kerupuk lomang ini. Diharapkan juga dengan adanya Perguruan Tinggi melakukan pendampingan terhadap KUBE ini, usahanya makin berkembang kedepannya. Pemasaran produk makin berkembang, tidak hanya lokal, tetapi juga nasional, bahkan internasional.

Adapun solusi yang ditawarkan untuk permasalahan mitra tersebut adalah sebagai berikut:

1. Pelatihan pengelolaan keuangan rumah tangga dan pembukuan usaha (arus kas).

2. Pelatihan pengembangan ide usaha dan perancangan Business Plan sebagai syarat pengajuan modal kepada pihak investor.

3. Pelatihan dan perancangan kemasan dan merk.

4. Memunculkan merk produk yang mengikuti standar merk dagang dan kemasan yang baik (ada komposisi bahan, halal, pendaftaran POM dan Dinas Kesehatan serta no hp KUBE)

5. Peningkatan area pemasaran. Produk akan akan ditawarkan dan dititipkan kesejumlah mini market/supermarket. Dengan pengelolaan dan promosi yang baik bisa berakibat area pemasaran bisa meluas.

\section{METODE PENGABDIAN}

Metode pelaksanaan kegiatan dilakukan dengan : pembinaan, pelatihan, pendampingan dan konsultasi secara terstruktur terhadap berbagai hal yang menjadi permasalahan KUBE Berkat Yakin. Disamping itu evaluasi terhadap tahapan-tahapan pelaksanaan kegiatan tersebut akan selalu diikuti dengan evaluasi guna dapat menyempurnakan tindakan berikutnya dalam upaya membantu mitra.

a. Sosialisasi Program

Pelaksanaan kegiatan diawali dengan sosialisasi program kepada KUBE Berkat Yakin mengenai lingkup program yang akan dilaksanakan, waktu pelaksanaan kegiatan, tahapan kegiatan, pendampingan, evaluasi kegiatan dan monitoring.

b. Pendampingan Kegiatan

Kegiatan Pendampingan dilakukan sesuai kebutuhan dan dilakukan pada semua tahapan kegiatan, mulai dari pembenahan manajemen usaha, perancangan desain kemasan produk yang bernilai jual hingga hingga pengembangan pemasaran produk.

c. Evaluasi Kegiatan dan Monitoring

Evaluasi dilakukan dalam upaya memaksimalkan hasil kegiatan sesuai dengan target yang sudah ditentukan. Evaluasi dilakukan terhadap semua bentuk kegiatan yang dilakukan dalam semua tahap kegiatan. Apabila terdapat kegiatan yang memberikan hasil yang tidak maksimal maka dilakukan upaya penyempurnaan kegiatan tersebut.

\section{HASIL DAN PEMBAHASAN}

Kegiatan PKMS ini telah dilaksanakan sejak bulan Juli 2019. Kegiatan dilakukan di Desa Merangin, Kecamatan Kuok, Kabupaten Kampar. Pembinaan dilakukan 
kepada mitra yaitu KUBE Berkat Yakin, diketuai oleh Ibu Husni Marti. KUBE ini telah menghasilkan aneka cemilan khas Kampar. Beberapa produk yang telah dihasilkan antara lain : Kerupuk Lomang, Kerupuk Jengkol, dan cemilan khas Kampar lainnya. Produk utama dari kedua KUBE ini adalah Kerupuk Lomang. Kerupuk Lomang yang telah mereka hasilkan ini memiliki rasa spesifik, lebih gurih, beda dari kerupuk berbahan dasar ubi kayu lainnya. Mereka sudah mengembangkan 2 rasa kerupuk lomang, yaitu dikenal dengan "kerupuk lomang lado merah" dan "kerupuk lomang lado hijau".

A. Tahap Sosialisasi

Pada tahap awal dilakukan diskusi bersama tim dengan ibu-ibu KUBE Berkat Yakin dan sosialisasi beberapa hal yang akan dilakukan, yaitu :

1. Produk unggulan KUBE yang akan fokus dikembangkan yaitu Karupuok Lomang.

2. Beberapa kekurangan dari produk yang ada saat ini yaitu :

a. Bentuk Kemasan kurang menarik

b. Pemasaran produk masih terbatas

3. Beberapa peluang yang diambil untuk pengembangan yaitu :
a. Bahwa Karupuok Lomang merupakan salah satu ciri khas cemilan Kuok
b. KUBE-KUBE sudah memiliki variasi karupuok

4. Rencana pengembangan yang dilakukan adalah selain memberikan pelatihan dan pendampingan terkait manajemen pengelolaan usaha juga dilakukan redesain kemasan produk dan pengembangan sarana untuk pemasaran produk.

B. Kegiatan Pendampingan

1. Pelatihan Dan Sosialisasi

Kegiatan pelatihan dan sosialisasi dihadiri oleh beberapa anggota KUBE. Berasal Ibu-Ibu Rumah Tangga di Desa Merangin, Kecamatan Kuok. Beberapa materi yang dibahas dan didiskusikan antara lain : Pelatihan pengembangan ide usaha, pengelolaan keuangan rumah tangga, Pelatihan standarisasi produk dan penggalian ide produk cemilan khas daerah lainnya, dan Pelatihan perancangan Business Plan sebagai syarat pengajuan modal kepada pihak investor.

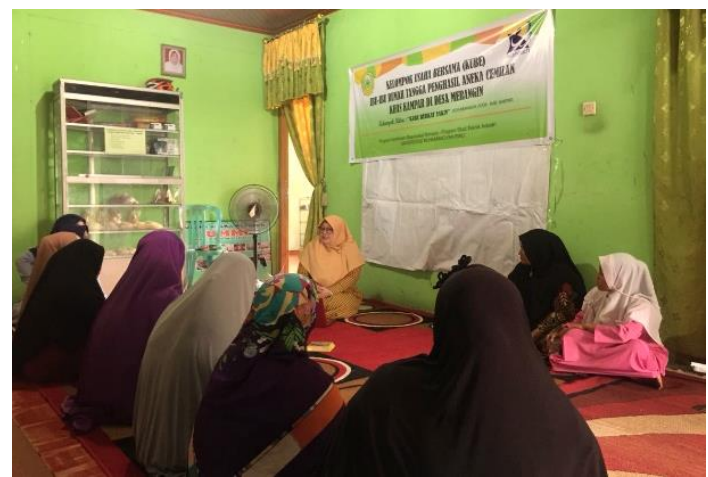

Gambar 3. Sosialisasi bagi KUBE Ibu-Ibu Rumah Tangga

2. Desain Kemasan

Kemasan Produk Karupuok Lomang masih sangat sederhana, akan dikembangkan beberapa desain kemasan terbaru.

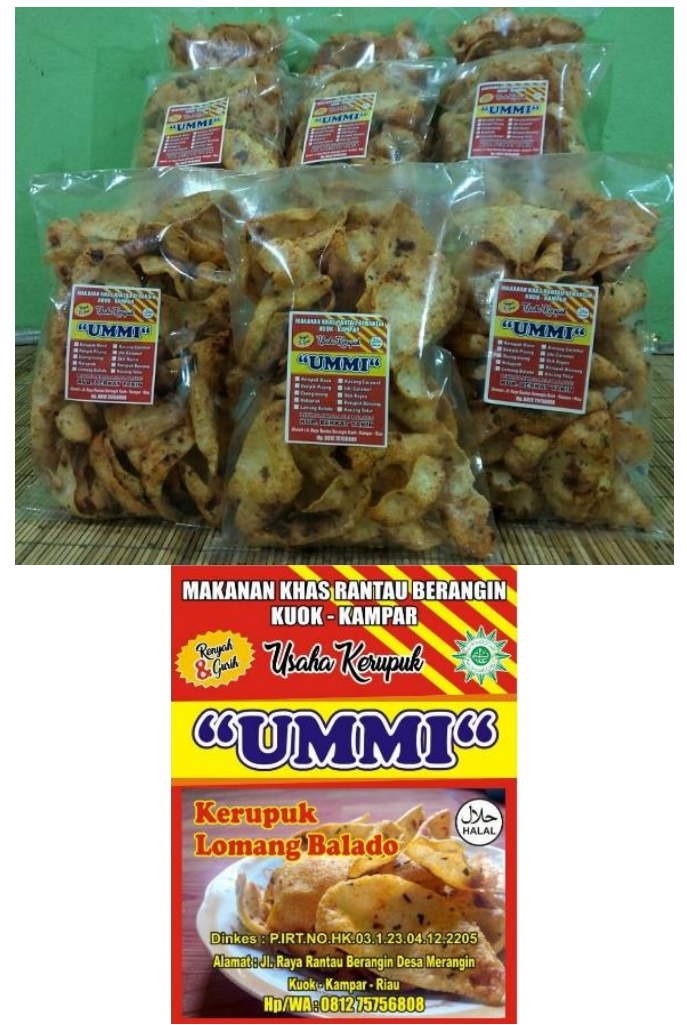

Gambar 4. Merk \& Kemasan Awal Karupuok Lomang 


\section{kemasan :}

Beberapa pengembangan desain

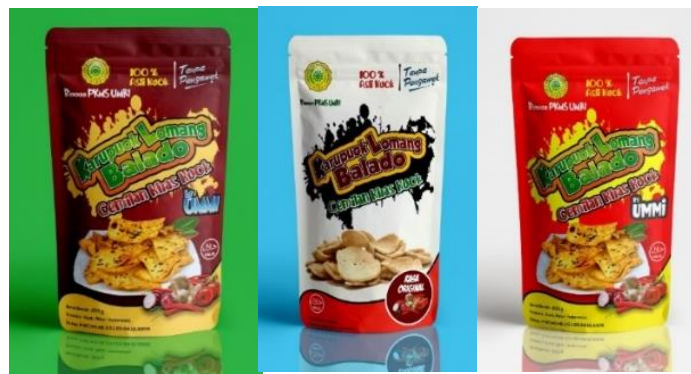

Gambar 5. Beberapa Pengembangan

Desain Kemasan

Sebagaimana kita temukan masalah yang dihadapi KUBE ini adalah, belum maksimalnya pemasaran produk, karena produk belum terlalu dikenal oleh masyarakat baik lokal maupun nasional. Salah satu penyebabnya adalah kemasan produk yang kurang menarik. Maka dari itu tim akan melakukan riset pengembangan terkait dengan kemasan produk karupuok lomang.

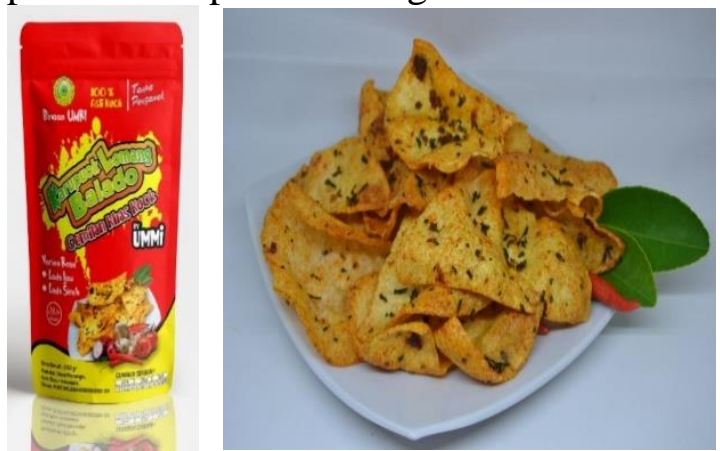

Gambar 6. Kemasan Baru

Kemasan baru karupuok lomang sudah selesai dan siap digunakan untuk pengembangan pemasaran berikutnya. Warna merah dan desain kemasan yang menarik, diharapkan dapat menjadikan karupuok lomang menjadi salah satu icon terbaik cemilan khas Kuok.

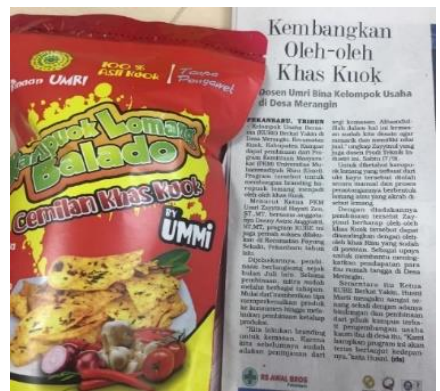

Gambar 7. Launching Karupuok Lomang Khas Kuok
Kemasan baru karupuok lomang mendapatkan tanggapan positif dari pelanggan. Mereka memberikan tanggapan bahwa desain terbaru ini sangat menarik dari segi warna dan display produk yang ada pada kemasan baru. Harapan pelanggan yaitu semoga ada peningkatan terkait varian lain dari karupuok lomang.

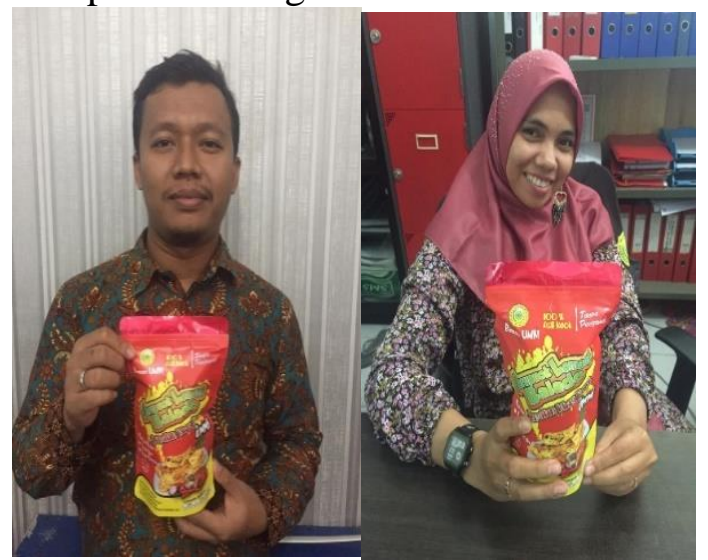

Gambar 8. Pelanggan Karupuok Lomang dengan Kemasan Baru

Tahap pengenalan produk Karupuok Lomang ke beberapa Gerai Pusat OlehOleh Khas Riau sudah dilaksanakan. Gerai pertama yang meminta produk karupuok lomang adalah "Klinik Selera". Tanggapan masyarakat sangat baik terhadap produk karupuok lomang. Berikut dokumentasi karupuok lomang khas Kuok di Gerai oleh-oleh.

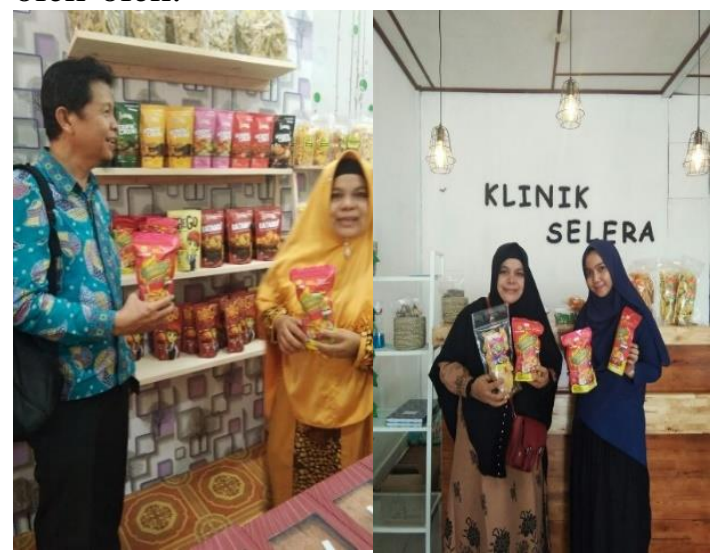

Gambar 9. Karupuok Lomang di Klinik Selera

Dengan adanya kerjasama antara KUBE Berkat Yakin dengan beberapa gerai oleh-oleh, diharapkan produk Karupuok Lomang makin dikenal oleh 
masyarakat lokal, nasional, bahkan Internasional.

Karupuok Lomang makin dikenal lebih dekat oleh masyarakat. Setiap kegiatan bazar Kabupaten Kampar bahkan Propinsi Riau, Karupuok lomang sudah dilirik masyarakat Riau. Salah satunya buktinya adalah karupuok lomang selalu mendapat undangan untuk Bazar di beberapa kegiatan pemerintah.

\section{SIMPULAN}

Beberapa kesimpulan dari pelaksanaan kegiatan pengabdian ini adalah sebagai berikut :

1. Mitra KUBE Berkat Yakin sudah mampu mengajak Ibu-Ibu Rumah Tangga di Desa Meranti Kecamatan Kuok untuk mengembangkan potensi diri.

2. Mitra masih membutuhkan bantuan dalam peningkatan pengembangan produk-produk unggulan lainnya.

3. Prodi Teknik Industri UMRI telah dipercaya untuk mengembangkan beberapa UMKM yang ada di Pekanbaru khususnya, Propinsi Riau umumnya, terlihat dari kegiatankegiatan Dinas Perindustrian dan Pengembangan Koperasi telah beberapa kali mengundang tim ahli dari Prodi Teknik Industri UMRI.

Beberapa hal yang telah dilakukan mulai dari pengembangan merek, proses pembuatan produk, pengembangan kemasan produk dengan desain menarik, pengembangan strategi pemasaran mitra. Dimana semuanya itu sangat disambut baik oleh mitra.

\section{UCAPAN TERIMAKASIH}

Kami sampaikan ucapan terimakasih kepada Lembaga Penelitian dan pengabdian Kepada Masyarakat Universitas Muhammadiyah Riau karena telah mendanai kegiatan pengabdian ini. Selain itu kami juga mengucapkan terimakasih kepada mitra KUBE Berkat Yakin yang diketuai oleh Ibu Husni Marti dan ibu-ibu anggota kelompok usaha bersama yang sudah ikut dalam kegiatan pengabdian ini.

\section{DAFTAR PUSTAKA}

[1]. Gaspersz, Vincent. 1997. Penerapan Konsep-konsep Kualitas dalam Manajemen Bisnis Total. Jakarta: Gramedia Pustaka.

[2]. Handoko, T.H. 2003. Manajemen Edisi 2. Yogyakarta: BPFE

[3]. Koentjaraningrat. 1997. Metodemetode Penelitian Masyarakat (edisi ketiga). Jakarta: PT Ikrar Mandiri Abadi.

[4]. Pedoman Penumbuhan dan Pengembangan Kelompok Usaha Bersama (KUBE), 2011, http://kuaci.blogspot.com/p/pedoman kube.html/ dikunjungi 12 Mei 2017

[5]. Schuler, R.S. dan Jakson S.E. 1997. Manajemen Sumber Daya Manusia. Jakarta: Erlangga

[6]. Tuty Movreynta, 2008, Implementasi Kelompok Usaha Bersama (KUBE) Tani di Dusun III Desa Pematang Lalang Kabupaten Deli Serdang.

[7]. Whitten, Jl, Bentley, lD, Dittman, kC, 2004, Metode Desain dan Analisis Sistem, edisi6, penerbit andi, Yogyakarta, terjemahan. Mc Graw hil education. 